\title{
MAKNA KEUNTUNGAN PENJUAL SALOME (STUDI FENOMENOLOGI HERMENEUTIK)
}

\section{THE MEANING OF PROFIT IN ACCORDANCE OF SALOME SELLER (HERMENEUTIC PHENOMENOLOGY STUDY)}

\author{
Wahyu Junaedi ${ }^{1}$, Chairun Nisa ${ }^{2}$, Indah Nurfazlillah ${ }^{3}$, \\ Silviana Gunarsih S.O. ${ }^{4}$, Titik Rodiyah ${ }^{5}$ \\ STIE Madani Balikpapan 1,2,3,4,5 \\ wahyujunaedi@stiemadani.ac.id ${ }^{1}$
}

\begin{abstract}
Salome seller profession is an alternative entrepreneurship for the community because the business is quite easy to do. This study aims to find the meaning of profit perceived by Salome sellers. Salome sellers who are able to survive long enough in pursuing their profession certainly have their own awareness in interpreting the benefits they get during selling Salome. This research was conducted on salome sellers who have pursued their profession for more than 10 years using a hermeneutic phenomenology approach. The results showed that salome sellers interpreted its advantages in terms of broad market segments, light business capital, and business management flexibility. The findings of the research's significance can also be taken into consideration in terms of measuring the risk of salome business performance from strategic, financial, and operational aspects.
\end{abstract}

Keywords: The Meaning of Profit, Hermeneutic Phenomenology, Risk of Business Performance

\begin{abstract}
ABSTRAK
Profesi penjual salome menjadi salah satu alternatif berwirausaha bagi masyarakat karena usaha tersebut cukup mudah dilakukan. Penelitian ini bertujuan untuk menemukan makna keuntungan yang dipersepsikan oleh penjual salome. Penjual salome yang mampu bertahan cukup lama dalam menekuni profesinya tentu memiliki kesadaran tersendiri dalam memaknai keuntungan yang diperolehnya selama berjualan salome. Penelitian ini dilakukan pada penjual salome yang telah menekuni profesinya selama 10 tahun lebih menggunakan pendekatan fenomenologi hermeneutik. Hasil penelitian menunjukkan bahwa penjual salome memaknai keuntungannya dalam hal luasnya segmen pasar, permodalan usaha yang ringan, dan fleksibilitas pengelolaan usaha. Temuan makna penelitian juga dapat dijadikan pertimbangan dalam hal mengukur risiko kinerja bisnis salome dari aspek strategis, finansial, dan operasional.
\end{abstract}

Kata Kunci: Makna Keuntungan, Fenomenologi Hermeneutik, Risiko Kinerja Bisnis

\section{PENDAHULUAN}

Profesi penjual salome menjadi salah satu alternatif berwirausaha bagi masyarakat karena usaha tersebut cukup mudah dilakukan. Para pelaku usaha ini biasanya berasal dari kelas ekonomi menengah ke bawah, karena modal yang dibutuhkan tidak seberapa besar (Prabowo \& Handoyo, 2016). Mereka biasanya kesulitan membuat usaha yang 
lebih besar, karena terkendala masalah modal. Para pelaku usaha ini banyak yang memutuskan untuk tidak meminjam uang sebagai modal dari bank atau lembaga keuangan lain, karena prosedur yang sulit dan susah dimengerti. Adapula yang memang tidak berminat meminjam uang, karena sudah nyaman dengan kondisi usahanya yang sekarang tanpa ada niat untuk memperluasnya.

Bagi masyarakat Kota Balikpapan Istilah penjual "salome" mungkin sudah tidak asing di telinga dan sering dijumpai di mana saja. Bagi masyarakat di beberapa daerah lain yang baru pertama kali mendengarnya, istilah "salome" mungkin akan terdengar asing. Salome adalah jajanan pinggir jalan yang bahan baku utamanya terbuat dari tepung kanji yang dicampur dengan daging ayam, sapi, atau ikan serta bumbu lain yang biasanya dinikmati dengan aneka saus. Di daerah lain jajanan semacam ini biasanya disebut dengan nama "pentol" atau "cilok". Salome merupakan jajanan yang diminati semua kalangan, karena rasanya yang enak dengan berbagai variasi serta harganya yang terjangkau.

Penjual salome merupakan suatu pekerjaan informal yang dikategorikan sebagai pedagang kecil. Layaknya seperti profesi informal lainnya, profesi penjual salome juga dilakukan untuk memenuhi segala kebutuhan hidup, apalagi di tengah himpitan kondisi ekonomi yang semakin sulit seiring dengan terus menaiknya harga-harga barang. Para penjual salome biasanya berjualan di tempat-tempat ramai di mana terdapat banyak orang, seperti di sekolah, pinggir jalan, dan tempattempat lain yang biasanya dijadikan tempat untuk bersantai. Mereka biasanya berjualan mulai dari pagi sampai sore atau bahkan terkadang sampai malam hari.
Profesi penjual salome sering
dipandang sebelah mata oleh masyarakat. Apalagi penjual Salome, sebagai salah satu jenis pedagang kaki lima, sering mendapatkan stigma yang kurang baik dari sisi kebersihan dan kesehatan makanannya. Masyarakat sering memberikan stigma bahwa pedagang kaki lima, termasuk penjual Salome, menjadi penyebab kemacetan, kekumuhan, tidak tertib, serta berasal dari golongan marginal (Prabowo \& Handoyo, 2016). Beberapa penjual pentol, sebagai sebutan lain dari salome, terkadang malah mengisi tempat-tempat di pinggir jalanan yang pada akhirnya mengganggu keindahan tata kota, sehingga sering berurusan dengan satpol PP saat penindakan relokasi (Akhadiyah \& Jatiningsih, 2017). Dari sisi pengembangan bisnis tentunya berjualan salome kurang menjanjikan, karena konsep jualannya yang sederhana dan pasarnya yang didominasi oleh rakyat menengah ke bawah. Saat berjualan terkadang mereka memperoleh keuntungan yang banyak, namun ada kalanya dagangan mereka sepi pembeli yang bisa mengakibatkan keuntungan yang diperoleh menjadi sedikit.

Meskipun demikian adapula penjual salome yang mampu bertahan belasan hingga puluhan tahun dalam berjualan salome. Peneliti tertarik untuk mencoba memahami makna keuntungan bagi penjual salome yang telah lama berjualan Salome belasan hingga puluhan tahun. Oleh karena itu menarik untuk melakukan penelitian terhadap pelaku UMKM yang telah lama berprofesi sebagai penjual salome dalam memaknai keuntungan yang mereka hasilkan dari kegiatan usahanya.

Dalam akuntansi, definisi keuntungan lebih sering dikaitkan dengan laba yang mana merupakan selisih dari pendapatan setelah 
dikurangi dengan beban (Sajuti, 2016). Di mata masyarakat keuntungan yang dimaksud biasanya dilihat dari kenaikan kemakmuran.

hasil penelitian yang dilakukan oleh Wafirotin \& Marsiwi (2015). Hal ini pula yang menjadi salah satu alasan mengapa penelitian mengenai pemaknaan keuntungan menjadi sangat menarik.

Penelitian terhadap pemaknaan keuntungan sudah cukup banyak dilakukan dengan menggunakan pendekatan kualitatif.

Penelitian yang dilakukan oleh Wafirotin \& Marsiwi (2015) yang menghasilkan empat makna keuntungan, yaitu keuntungan materi, keuntungan spiritual, keuntungan kepuasan batin dan keuntungan berupa tabungan akherat, yaitu dengan mampu mencukupi kebutuhan keluarganya, menyekolahkan anak-anak mereka dengan harapan anak-anak mereka nanti sukses baik di dunia maupun di akherat.

Dari penelitian-penelitian yang sangat menginspirasi di atas, menunjukkan perbedaan mengenai makna keuntungan dari berbagai profesi berbeda. Fenomena pemaknaan keuntungan yang berbeda dari berbagai sudut pandang ini menunjukkan adanya perbedaan persepsi individu mengenai keuntungan berdasarkan apa yang mereka alami selama hidupnya. Pengalaman yang dialami suatu individu akan mempengaruhi mereka dalam menafsirkan suatu hal, salah satunya adalah makna dari keuntungan.

Penelitian ini dilakukan untuk mengetahui pemaknaan keuntungan bagi penjual salome di Balikpapan dalam pengalaman hidup mereka berjualan dalam waktu yang lama. Penjual salome sebagai profesi pekerjaan informal yang sering menerima stigma negatif pada beberapa aspek tertentu barangkali memiliki kesadaran yang terpendam mengenai keuntungan yang mereka peroleh pada saat memilih berjualan salome dalam waktu yang lama. Keuntungan tersebut barangkali tidak hanya berupa keuntungan materiil berupa laba akuntansi, namun juga keuntungan non materiil. Penelitian ini diharapkan dapat mendeskripsikan esensi pemaknaan keuntungan bagi penjual salome dalam usaha mereka sehingga penelitian ini dapat menghasilkan makna-makna keuntungan lain yang belum bisa diungkapkan oleh penelitian sebelumnya.

\section{METODE PENELITIAN}

Penelitian ini menggunakan paradigma interpretif dengan pendekatan fenomenologi hermeneutik. Pendekatan fenomenologi hermenutik merupakan turunan dari filsafat fenomenologi dan hermeneutik yang ditemukan oleh Martin Heidegger (1889 - 1976). Secara filosofis pendekatan ini menganggap bahwa kesadaran subyektif individu mengenai pengalamannya terhadap suatu fenomena sosial perlu untuk ditafsirkan, agar cerita pengalaman yang diungkapkan memiliki gambaran yang lengkap. Dalam pendekatan ini peneliti berusaha untuk membuat gambaran yang luas dan mendalam terkait fenomena menggunakan intuisinya, sementara seluruh fokusnya pada mengungkapkan, bukan menemukan keakurasian.

Heidegger berpendapat bahwa dalam fenomenologi hermeneutik pemaparan fenomena secara deskriptif harus didasari pemahaman terhadap fenomena yang dialami informan, serta tidak boleh diintervensi dengan pemahaman yang berasal dari teori a priori. Fenomenologi Hermeneutik menjadikan pengalaman manusia terhadap suatu fenomena nampak hidup melalui penjelasan deskriptif yang luas 
dan mendalam. Hasil akhir dari proses tersebut adalah penciptaan suatu makna atau pencarian suatu inti sari dari kesadaran. Melalui inti sari tersebut pembaca dapat lebih memahami perspektif informan mengenai suatu fenomena yang menjadi isu sentral dalam penelitian ini, yaitu makna keuntungan berjualan salome.

Teknik pengumpulan data yang digunakan oleh peneliti dalam proposal ini mengikuti lingkaran pengumpulan data dalam penelitian kualitatif yang disarankan oleh Creswell (2015). Pertama, peneliti menentukan tempat/individu. Peneliti telah memilih penjual salome sebagai sekelompok individu yang diteliti. Peneliti telah mewawancarai 7 (tujuh) orang informan terkait pengumpulan data. Informan tersebut merupakan penjual salome yang berada di kota Balikpapan. Kedua, memperoleh akses dan membangun hubungan. Peneliti dalam hal ini memperoleh akses melalui beberapa penjual salome yang peneliti kenal atau penjual salome langganan peneliti, dan penjual salome yang peneliti survei yang telah berjualan lebih dari 10 tahun.

Ketiga, penentuan informan. Dalam studi fenomenologi hal yang penting untuk diperhatikan dalam penentuan informan adalah memastikan bahwa informan yang dipilih telah mengalami fenomena yang dipelajari (Creswell, 2015). Oleh karena itu peneliti menggunakan strategi sampling purposeful dengan cara menentukan informan menggunakan beberapa kriteria. Ada empat kriteria untuk menentukan informan antara lain: penjual salome yang ada di kota Balikpapan yang berjualan lebih dari 10 tahun, enjual salome yang berjualan secara rutin bukan di saat-saat tertentu saja, penjual salome yang termasuk pedagang kecil yang tidak mempunyai outlet atau cabang, serta tidak membuat pembukuan akuntansi, dan penjual salome yang mau menjadi informan dan bersedia untuk diwawancarai.

Keempat, data dikumpulkan dengan wawancara semi terstruktur. Peneliti melakukan wawancara semi terstruktur yang dilakukan dalam suasana tidak formal dan dengan pertanyaan yang mengarah pada kedalaman informasi terkait tujuan penelitian. Peneliti membuat daftar pertanyaan yang ingin ditanyakan, namun daftar pertanyaan tersebut tidak kaku atau masih memungkinkan untuk berkembang sesuai kondisi di lapangan.

Pada penelitian yang menggunakan pendekatan fenomenologi hermenutik, analisis data biasanya menggunakan teknik hermeneutic cycle. Proses hermeneutic cycle terdiri atas reading, reflective writing, dan interpreting. Secara sistematis, proses analisis data ini akan dilakukan melalui tiga langkah. Pertama, peneliti akan melakukan reduksi data diawali dari pembacaan data secara berulang-ulang (reading). Reduksi data adalah proses pemilihan, pemusatan perhatian pada penyederhanaan, pengabstrakan, dan transformasi data kasar yang muncul dari catatan-catatan tertulis di lapangan dan hasil rekaman wawancara. Reduksi data dilakukan sebagai proses penyempurnaan data, baik dengan pengurangan terhadap data yang dianggap kurang perlu atau tidak relevan maupun penambahan data yang dirasa masih kurang. Dengan demikian data yang akan direduksi memberikan gambaran yang lebih jelas, dan mempermudah peneliti untuk melakukan pengumpulan data selanjutnya dan mencarinya bila diperlukan. Kedua, peneliti akan melakukan analisis hermeneutika dengan cara menafsirkan teks (pernyataan) dan ekspresi informan 
menjadi deskripsi cerita (reflective writing) ke dalam beberapa tema. Ketiga, peneliti membuat sintesis makna dari keseluruhan tema reflective writing, sehingga dihasilkan sebuah makna yang konkret (interpreting) tentang keuntungan penjual salome.

\section{HASIL DAN PEMBAHASAN Segmen Pasar yang luas dan Aliran Kas yang stabil.}

Bapak Bangit adalah salah satu penjual salome yang telah malang melintang berjualan salome sekitar 15 tahun. Setelah berkelana dalam perantauannya merasakan berbagai jenis pekerjaan, akhirnya Bapak Bangit memutuskan untuk membuka usaha salome yang dia tekuni hingga saat ini. Awal mula pergi ke tanah rantau niat Bapak Bangit adalah mencari pekerjaan dengan bermodalkan ijazah SMP. Berpindah - pindah dari satu perusahaan hingga pernah ikut bantu berjualan siomay. "Walah, merantau kemana-mana le, kan di siomay, terakhirnya ya ini salome ini", demikian pernyataan Bapak Bangit kepada peneliti. Beliau pernah lama bekerja di Bungalon, Sangata dan di sana pernah mencicipi bekerja sebagai buruh bangunan, namun tidak betah dan akhirnya memutuskan hijrah ke Balikpapan. Beliau menyatakan kepada peneliti, "ya, lamanya ke bungalon sana. Sangata. Di sana sebulan di bangunan. Gak krasan ya lari kesini".

Di Balikpapan Bapak Bangit berjualan salome bersama istrinya di sekitar masjid di dalam pasar kebun sayur. Di sekitaran lingkungan masjid juga berdiri sekolah islam terpadu (IT) yang siswanya lumayan ramai. Bapak Bangit mengakui siswa - siswi di sekolah IT tersebut adalah salah satu pelanggan utama yang mempengaruhi tingkat penjualan salomenya. Selain itu masyarakat yang beraktivitas di pasar juga sering membeli salome Bapak Bangit. Bapak Bangit memberikan penjelasan kepada peneliti, "Orang luar sama anak-anak sekolah itu. Pas hari liburan kan susah. Kadang-kadang untuk modal ae ndak cukup. Kalau ada anak sekolah ya lumayan". Saat liburan sekolah adalah saat yang kurang menguntungkan bagi bisnis Bapak Bangit, karena dia kehilangan pelanggan utamanya. Buat memutar modal saja kadang agak kesulitan ketika beliau berjualan di masa libur sekolah.

Bapak Bangit mengakui bahwa dirinya perantau yang sejak awal pergi merantau berniat untuk mencari pekerjaan sebagai karyawan perusahaan. Bapak Bangit mengaku kepada peneliti awal mula terjun di dunia dagang karena diajak oleh teman - teman kampungnya. “...Nah ini kan ngikuti teman-teman aja. temannya dagang ya ikut dagang. Soalnya kan di kota, kalau di kampung ya larinya ke sawah, mau kemana lagi", demikian pernyataan beliau kepada peneliti. Di kampung beliau memiliki orang tua yang berprofesi sebagai petani. Dengan kata lain beliau sesungguhnya tidak mewarisi darah seorang pedagang dalam dirinya. Pengaruh yang kuat dari lingkungannya di kota Balikpapan serta persepsi mengenai ketidakmujurannya berkarir sebagai karyawan membuat beliau memutuskan untuk berdagang.

Saat mencoba peruntungan di bisnis beliau mulai dengan berjualan bakso, soto, dan rawon. "Kalau untuk dodolan bakso, soto itu di pasar tungkar. Rapak sana. Sebelum lampu merah itu. Pas jualan Koran foto kopi situ. Itu lama juga jualan di situ. Ada 5 tahunan jualan bakso soto", demikian beliau menceritakan pengalamannya. Saat berjualan soto dan bakso, usaha Bapak Bangit tidak bertahan lama, karena pembelinya sepi. Padahal jika dilihat dari lokasinya cukup strategis, 
yaitu di pertigaan sebelum lampu merah Rapak. Setelah bertahan sekitar 5 tahunan beliau memutuskan untuk beralih profesi menjadi penjual Salome.

Sekitar 15 tahun bertahan menjadi penjual salome mengisahkan banyak suka duka yang didapatkan oleh Bapak Bangit. Terlepas dari suka duka yang ada, 15 tahun tentu bukan waktu yang sebentar. Tentu ada hal yang menarik untuk ditelusuri lebih dalam mengenai alasan Bapak Bangit bertahan hingga 15 tahun berprofesi sebagai penjual salome. Saat peneliti melontarkan beberapa tema pertanyaan mengenai bagaimana Bapak Bangit memaknai keuntungannya hingga beliau mampu bertahan berdagang salome hingga 15 tahun, peneliti menangkap setidaknya ada dua makna yang beliau ungkapkan kepada peneliti.

Makna pertama mengenai segmen pasar salome yang luas. Bapak Bangit menjelaskan kepada peneliti, "Dulu bakso, soto, rawon. Sepi anunya. Kalau ini salome kan banyak yang makan . Anak sekolah, orang kerja, orang tua juga". Menurut Bapak Bangit bejualan salome lebih menguntungkan dari pada berjualan bakso, soto, rawon yang sebelumnya beliau sempat tekuni. Berjualan bakso, soto, dan rawon itu keuntungannya sedikit. Segmen pasarnya kebanyakan dari orang-orang tua dan dewasa yang mampir untuk menghilangkan rasa lapar disaat waktuwaktu makan.

Makna yang kedua menurut beliau adalah aliran kas (cash flow) yang lebih stabil dibandingkan ketika masih bekerja sebagai karyawan. Berikut penjelasan beliau kepada peneliti, "ya kan ya ini yang dimakan wes cukup gitu lo. Hari - hari kan megang uang kalau dagang gini. Kerja kan satu bulan sekali. Belum tentu berhasil kalau kerja. Saya kerja di siomay itu kan, (karena) kayu kan jarang-jarang ada. Jadi cuman pitung bulanan aja. Gajinya nggak ada."

Menurut beliau berjualan salome justru memberikan kecukupan, karena setiap hari menghasilkan pemasukan kas. Saat bekerja sebagai karyawan belum tentu setiap hari memegang kas, karena pencairan gaji setiap bulan. Bahkan gaji bulanan bisa bersaldo minus, jika pinjaman atau kewajiban bulanan lebih besar dari pada penerimaan bulanan. Mengenai hal ini Bapak Bangit menyampaikan, "habis. Sama aja kerja di siomay itu pasti ngutang, karena untuk makan. Belum sampek sebulan habis. Siomay kan borongan ndak harian". Saat menjadi karyawan Bapak Bangit merasa aliran kas justru minus tiap bulannya, karena gaji belum sampai satu bulan sudah habis dan akhirnya berhutang untuk menutupi keperluan sehari-hari. Bulan depannya gaji sudah harus dipotong dengan hutang bulan lalu. Bapak Bangit juga menuturkan kepada peneliti berkat hasil usahanya berjualan salome beliau mampu memberikan uang saku sekolah anak-anak dan cucunya, bahkan mampu memperbaiki rumah

"Alhamdulilah lah bisa mencukupi untuk biaya sekolah anak, ya sedikit-sedikit untuk sangu sekolah itu, penting makannya itu, sangu sekolah itu penting juga..."

"mau pindah profesi ya apa yang mau dipindahin. Ini aja tekuni sudah, kan sudah untung apa rumah sudah. Tapi ya numpang aja tanahnya punya pertamina.

Bapak Bangit mampu merenovasi rumah dari hasil berjualan salome, meskipun rumah tersebut dibangun di atas tanah PT. Pertamina. Hal ini menunjukkan bahwa sesungguhnya dari keuntungan 
berjualan salome Bapak Bangit masih bisa menyisihkan uang di luar untuk memenuhi kebutuhan pokok sehari-hari. Dengan cash flow yang lebih stabil Bapak Bangit tidak lagi gali dan tutup lubang tiap bulannya untuk memenuhi kebutuhan hidupnya.

\section{Efisiensi Waktu dan Kepuasan Batin}

Bapak Agus merupakan salah satu penjual salome yang telah berjualan sekitar 10 tahun. Beliau berasal dari jawa tengah daerah klaten kabupaten krucu. Bapak Agus telah merasakan berbagai macam pekerjaan hingga akhirnya beliau memutuskan untuk berjualan salome. Awal mulanya Bapak Agus merantau berniat untuk mencari pekerjaan dengan bermodalkan ijazah SMA. Beliau menyatakan kepada peneliti "ndak, kerja dulu. Dengan kondisi tahun 2007 agak susah nyari kerjaan kan , akhirnya tahun 2008 mulai jualan salome." Beliau pernah bekerja di proyek, karena terkena tipu akhirnya memutuskan untuk berjualan salome. Beliau menyatakan kepada penelti, "iya, rencana kan cari kerja dulu, nah dikarenakan yah tadi, tahun 2007 agak susah cari kerjaan, yah kerja di proyek sering ketipu gak dibayar akhirnya jual salome."

Di Balikpapan, Bapak Agus berjualan salome sendirian dengan menggunakan sepeda motor. Bapak Agus biasanya berjualan di daerah Lapangan Poni tepatnya di dekat rumah sakit bersalin sayang ibu. Bapak agus mengakui bahwa pembelinya sebagian besar yaitu masyarakat yang berlalu lalang di sekitar lapangan poni. Selain itu pegawai rumah sakit serta anak-anak sekolah juga sering membeli salome Bapak Agus. Hal ini karena di sekitaran lapangan poni juga terdapat beberapa sekolah yaitu SMA Ibnu Kaldun, SD 09 dan SD 04.
Bapak Agus mengakui bahwa dirinya merantau ke Balikpapan sejak awal berniat untuk mencari pekerjaan sebagai karyawan perusahaan. Bapak Agus mengaku kepada peneliti awal mula terjun ke dunia dagang karena diajak oleh teman-teman di sekitar rumahnya. Beliau menyatakan kepada peneliti,

"dulu karena modal , terus lingkungan nya juga lingkungan salome dulu itu di patriot. Patriot itu kan pusatnya salome mantingan itu, jadi dulu itu begitu cari kerja susah sering bengong di depan pintu kan hehe , dipanggil sama temanteman yang orang mantingan itu diajakin. Mas dari pada sampeyan bingung cari kerjaan, jualan salome aja . Aku bilang gak punya alatnya gak ada modalnya gitu, yah dengan kebaikan mereka dikasih pinjam alat, alat buat nyukil itu, cara bikinnya diajarin sama temanteman orang mantingan, yah mungkin sampe sekarang kalo dulu kepepet, kalo sekarang keenakan jualan terus."

Beliau berjualan salome berkat kebaikan dari teman-teman beliau. Di kampung, beliau memiliki orang tua yang berporfesi juga sebagai pedagang es. Berikut penjelasan beliau kepada peneliti,

"Mungkin Orang tua dulu, orang tua dari istri, jawa, jualan. Kalau almarhum baBapak saya di palembang itu jualan juga. Tapi bukan jualan kayak gini, jualan es. Iya... yah mungkin kata orang itu dari keluarga , saudara mestinya ada salah satu yang ngikutin jejak orang tua." 
Dengan kata lain beliau mewarisi darah seorang pedagang dari orang tuanya, serta didorong pula oleh ajakan dari lingkungan sosial yang mendukung. Pengaruh yang kuat dari lingkungan keluarga serta temantemannya dan persepsi mengenai ketidakmujuran dalam berprofesi sebagai karyawan yang akhirnya membuat beliau memutuskan untuk berdagang.

Saat mencoba peruntungan di dunia dagang, beliau memulai dengan berjualan salome, awal mulanya beliau berdagang salome dengan cara di pikul, karena modal yang dimiliki masih sedikit. Kemudian Bapak Agus beralih profesi menjadi penjual sosis, cendol, es doger. Beliau menyatakan kepada peneliti, "iya , pertama salome dulu, terus agak jenuh juga kan ganti sosis ternyata kurang (waktunya), ganti cendol, cendol kurang juga, esdoger ganti, masih kurang juga akhirnya balik lagi (salome). Kembali ke laptop." Menurut beliau awalnya berjualan salome, kemudian karena jenuh akhirnya beralih ke dagang sosis, cendol, dan kemudian es doger. Namun ternyata ketika beralih ke dagang sosis, cendol dan es doger, Bapak Agus merasa waktunya kurang yang artinya membutuhkan jam yang lebih lama berjualan. Hal ini dikarenakan Bapak Agus harus mencari pelanggan yang baru serta perlunya adaptasi lagi. Karena merasa nyaman dengan berdagang salome, hingga akhirnya Bapak Agus memutuskan untuk kembali berjualan salome.

Selama 10 tahun berjualan salome mengisahkan suka dan duka yang didapat oleh Bapak Agus. Terlepas dari suka duka yang ada, 10 tahun tentu bukan waktu yang sebentar. Tentu ada hal yang menarik untuk ditelusuri lebih dalam mengenai alasan Bapak Agus bertahan hingga 10 tahun berprofesi sebagai penjual salome. Saat peneliti melontarkan beberapa tema pertanyaan mengenai bagaimana Bapak Agus memaknai keuntungannya hingga beliau mampu bertahan berdagang salome hingga 10 tahun, peneliti menangkap setidaknya ada dua makna yang beliau ungkapkan kepada peneliti.

Makna pertama mengenai keuntungan dianggap sebagai efisiensi waktu dan biaya. Bapak Agus menjelaskan kepada peneliti,

"Iya dari waktunya kerja, hasilnya juga. Waktunya kan mungkin kalau kita jualan salome istilahnya kan sudah terbiasa tuh jadinya kan langganannya sudah tau jam segininya jam segininya. Kalau doger, cendol dan lain-lain kan mencari langganan baru, itu aja waktunya kurang, jadi harusnya kita bisa pulang jam 4 jam 5, kadang sampai magrib jam 6 jam 7 baru pulang, itu pun gak habis. Ya gitu..ya intinya apa ya istilahnya itu yang sudah biasa kita jalanin itu yang lebih nyaman gitu loh.”

Menurut Bapak Agus salome lebih menguntungkan dibandingkan berjualan sosis, cendol dan es doger yang sebelumnya beliau sempat tekuni. Bapak Agus mengakui bahwa ketika berjualan sosis, cendol dan es doger penghasilannya lebih kecil, bahkan kadang-kadang merugi. Selain itu waktu yang diperlukan untuk berjualan juga lebih lama dibandingkan dengan berjualan salome. Oleh karena itu selain Bapak Agus mengalami kerugian dari sisi materi, beliau juga mengalami kerugian di sisi waktu.

Makna kedua menurut beliau adalah kepuasan batin. Bapak Agus menjelaskan kepada peneliti, "Maksudnya gini yah, keuntungan itu 
kan kita ambil dari sisi agama juga, bahwasannya yang penting cari barokahnya".

"Kalau banyak harta sendiri kalau kita kurang bersyukur,ya jadi gak ada apa-apanya. Istilahnya Cuma uang aja. Tapi kalau kita ambil ke sisi agama, bahwasannya rejeki itu sudah disiapkan sama Allah dan tinggal kitanya menyemputnya. Nah dengan cara apa kita menjemput rejeki itu. Ada yang kerja dikantor, ada yang jadi PNS, ada yang jualan kan gitu kan.Kan makna dari keuntungan itu sebenarnya sesuatu yang sudah disiapkan sama Allah dan kita tinggal menjemputnya aja"

Menurut beliau keuntungan yang diperoleh merupakan rezeki yang harus disyukuri karena rezeki sudah diatur oleh Allah SWT. Sehingga berapun keuntungan yang diperoleh Bapak Agus harus tetap disyukuri.

"Kemaren sempet. Sempet. Sempet juga ada tawaran kerja . tapi setelah dihitung hitung, kita hitungannya kan gini , kalau sehari lima ratus sebulan berapa yah.lima belas juta yah,Nah disitu cari kerja sebulannya UMK, Tiga juta, sepertiga yah. Sepertiganya dari itu . seperlima malahan. Seperlima.jadi kita tetep alhamdulillah, bertahan dijualan. Kemudian sisi kenyamanan, saya itu kerja di Jakarta itu sepuluh tahun diperusahaan asing. Sepuluh tahun, tapi dapetnya cape aja. Lahirnya itu.Prinsip soalnya . saya itu paling gak bisa ditekan. Jadi kalau kerja itu saya itu pokoknya kalau job desknya sudah selesai mau istirahat saya itu..Nah maunya orang luar kan kadang- kadang kan, suruh cari kesibukan, cari muka gitu loh.Pura-pura kerja ngapain lah. Kalau aku itu orangnya gak mau. Kalau aku job desk selesai ya istirahat. Nanti waktunya kerja ya kerja lagi.. gitu.."

Menurut Bapak Agus berjualan salome justru memberikan kecukupan dibandingkan menjadi karyawan. Hal ini karena ketika menjadi karyawan gaji yang diperoleh hanya seperlima dari pendapatan yang diperoleh ketika berjualan salome. Selain itu, menurut Bapak Agus berdagang salome justru memberikan kenyamanan dibandingkan ketika menjadi karyawan. Hal ini karena lingkungan kerja ketika menjadi karyawan yang memiliki prinsip yang berbeda dengan pendirian Bapak Agus.

Bapak Agus juga menuturkan kepada peneliti berkat hasil usahanya berjualan salome beliau mampu membiayai pendidikan anak-anaknya, membeli sepeda motor, bahkan sisanya dapat ditabung. "Ya tadi, ya buat sewa rumah biaya sekolah, kalau bisa nabung, nabung, sedikit-sedikit kan" demikian pernyataan beliau kepada peneliti.

\section{Kebutuhan Modal Kecil dan Berpeluang Mendukung Kebutuhan Masa Depan Anak.}

Bapak Slamet adalah salah satu penjual salome yang sudah malang melintang berjualan salome selama 15 tahun. Beliau berasal dari kota kediri, dan sekarang sudah berusia 49 tahun. Bapak Slamet hanya menyelesaikan sekolah sampai jenjang SD saja. Setelah berkelana dalam perantauannya merasakan berbagai jenis pekerjaan, akhirnya Bapak Slamet memutuskan untuk membuka usaha salome yang dia tekuni hingga saat ini. Awal mula Bapak Slamet merantau ke kota 
Balikpapan pada tahun 1991, niat Bapak Slamet awalnya mencari pekerjaan. Bapak Slamet sebelumnya hanya bekerja di toko-toko. Beliau menyatakan kepada peneliti "jualan aja..Yooo.. ikut sana sini kerja mana mana.. kejar setoran". Berbagai pekerjaan telah ditekuni oleh Bapak slamet hingga akhirnya Bapak slamet memutuskan untuk berdagang, "Ya kerja macam-macam kerjaan sudah. Ya pokoknya yang penting kerja. Gak langsung gini ya ya kerja-kerja di toko, ya kerja macam-macam sudah." Demikian pernyataan Bapak Slamet kepada peneliti.

Di Balikpapan Bapak Slamet berjualan salome di persimpangan yang berada di depan pasar pandan sari. Bapak Slamet mengakui bahwa pelanggannya yaitu masyarakat yang beraktivitas di pasar pandan sari merupakan pelanggan utamanya. "Ya di pasar yah orang orang yang lewat ini. Orang -orang dari mana mana ini" demikian pernyataan Bapak Slamet kepada peneliti.

Bapak Slamet mengakui bahwa dirinya merantau di Balikpapan tidak langsung berdagang tetapi bekerja di toko. Bapak Slamet mengakui awal mula berdagang karena kemauan sendiri, serta dipicu pula oleh penghasilan sebagai karyawan toko yang kecil. Di kampung beliau memiliki orang tua yang berprofesi sebagai petani. Dengan kata lain beliau sesungguhnya tidak mewarisi darah seorang pedagang dalam dirinya. Adanya persepsi mengenai kurang untungnya berkarir sebagai karyawan membuat beliau memutuskan untuk berdagang. "Namanya kalau kita ikut orang kan nda cukup" demikian pernyataan Bapak Slamet kepada peneliti.

Saat mencoba peruntungan di bisnis beliau mulai dengan berjualan es, es cendol serta salome goreng. "Yo jualan es .ya jualan pokoknya jual gini gini. jual cendol jual salome goreng, gak langsung gini enda. Ganti ganti namanya orang jualan" demikian pernyataan yang disampaikan kepada peneliti. Bapak Slamet memberikan penjelasan kepada peneliti "Yoo namanya orang pindah pasti untungnya lebih cari yang lebih enak dari yang anu". Saat berjualan es cendol, usaha Bapak Slamet tidak bertahan lama, karena pembelinya sedikit. Sehingga akhirnya beliau memutuskan untuk beralih profesi menjadi pedagang salome.

Selama 15 tahun bertahan menjadi penjual salome mengisahkan banyak suka duka yang didapatkan oleh Bapak Slamet. Terlepas dari suka duka yang ada, 15 tahun tentu bukan waktu yang sebentar. Tentu ada hal yang menarik untuk ditelusuri lebih dalam mengenai alasan Bapak Slamet bertahan hingga 15 tahun berprofesi sebagai penjual salome. Saat peneliti melontarkan beberapa tema pertanyaan mengenai bagaimana Bapak Slamet memaknai keuntungannya hingga beliau mampu bertahan berdagang salome hingga 15 tahun, peneliti menangkap setidaknya ada dua makna yang beliau ungkapkan kepada peneliti.

Makna pertama menurut Bapak Slamet keuntungan dapat diartikan sebagai modal kecil. Bapak Slamet menjelaskan kepada peneliti

"Iya namanya modal kecil untungnya pasti kecil. Kecuali kita modal gede trus jadi menguntungkan trus untungnya jadi gede. Iya itu kalau orang jualan itu.gak masalah untungnya. Gak ada untung.kalau orang jualan pasti yang dicari untung. Kalau modalnya kecil ya untungnya kecil." 
Menurut Bapak Slamet berjualan salome hanya membutuhkan modal yang kecil Sedangkan apabila berjualan seperti soto, bakso dan sebagainya membutuhkan modal yang besar. Sehingga alasan beliau memilih berjualan salome yaitu dari sisi modal yang dibutuhkan kecil. Serta berjualan es cendol memperoleh keuntungan yang sedikit, bahkan terkadang merugi ketika di musim hujan. Bapak Slamet menyatakan kepada peneliti,

"Yoo kalau namanya jual es kalau hujan mana bisa jualan. Kalau jualan salome hujan, terang kan kita tetep jualan. Kalau jual es tetep habis, esnya cair. Kalau salome kan biar hujan biar panas kan tetap jalan. Kalau minum es dingin dingin mana mau kalau hujan. Jadi pindah biar kita tetep jalan hujan jalan panas jalan. Kalau jual es tetep jalan juga tapi esnya habis juga. Yang habis lain jualannya tapi esnya yang cair."

Menurut beliau salome bisa dinikmati di segala cuaca, baik cuaca panas maupun hujan, sedangkan berjualan es pada saat musim hujan akan sepi peminatnya. Sedangkan Makna yang kedua menurut beliau yaitu mampu mendukung masa depan anak. Berikut penjelasan beliau kepada peneliti, "Yoo..buat masa depan anaknya".

"Iya.. betul sudah kalau ada sisa..kalau gak ada sisa ya itu..kan buat nyekolahkan anaknya kan buat anaknya..gak mungkin Bapakle ini mau sekolah lagi.kalau buat Bapakle.lah iyo"

Menurut beliau berjualan salome memberikan keuntungan yaitu untuk masa depan anak-anaknya, sedangkan sisanya digunakan untuk kebutuhan sehari- hari. Bapak Slamet menuturkan kepada peneliti berkat hasil usahanya berjualan salome beliau mampu memenuhi kebutuhan sehari hari, serta untuk biaya menyekolahkan anaknya, bahkan sampai perguruan tinggi. Hal yang diutamakan oleh Bapak Slamet adalah kebutuhan anak-anaknya. Sehingga pendidikan anaknya adalah nomor satu yaitu agar anaknya berhasil. Sehingga keuntungan dapat disimpulkan, yaitu berpeluang mendukung kebutuhan masa depan anak.

\section{Biaya Modal Kecil dan Keuntungan Memuaskan, serta Fleksibilitas Pengelolaan}

Bapak Niko merupakan salah satu penjual salome yang merintis usahanya pada tahun 2007 hingga sekarang atau kurang lebih 12 tahun. Setelah kurang lebih 30 tahun merasakan suka dan duka menjalani berbagai pekerjaan, akhirnya Bapak Niko memutuskan untuk menjadi seorang penjual salome. Namun, sebelum menjadi penjual salome, beliau telah merantau ketempat yang cukup jauh dengan bermodal ijazah SLTA dari Flores, Nusa Tenggara Timur yang meruBapakan tanah kelahirannya pada tahun 70-an. Sebelumnya, beliau meruBapakan seorang pengusaha besar yang cukup sukses di Surabaya, namun menurut beliau menjadi seorang pengusaha dan mendapatkan pendapatan yang fantastis tidak cukup untuk memberikan kepuasan hati yang sebenarnya. Akhirnya beliau memutuskan untuk pergi dari Surabaya dan merantau kembali ke Balikpapan.

Di Balikpapan Bapak Niko berjualan salome di Lapangan merdeka, tepatnya di sekitar Masjid Istiqomah, namun kadang beliau pindah di dekat 
Tugu Australia. Lapangan Merdeka meruBapakan pusat keramaian, karena selalu ada warga Balikpapan yang melakukan aktivitas sore (jogging) ataupun hanya sekedar membeli jajanan kaki lima lainnya bersama keluarga mereka. Pada hari-hari biasa beliau berjualan mulai pukul 3 sore, namun jika pada hari libur beliau berjualan mulai pukul 6 pagi hingga 6 sore. Hari libur meruBapakan hari yang sangat baik untuk Bapak Niko, karena pendapatan yang dihasilkan akan bertambah hingga 3 kali lipat dari harihari biasanya. Selain itu Lapangan merdeka juga meruBapakan tempat yang sering diadakannya event-event seperti HUT TNI, HUT BHAYANGKARI dan lain sebagainya, ini akan membuat pendapatan Bapak Niko semakin meningkat.

Pada saat awal akan berjualan salome, beliau berfikir tidak membutuhkan modal yang besar seperti pada saat beliau menjadi seorang pengusaha.

"Modal ya modal sendiri. Modalnya sih ndak seberapa banyak karna waktu awal- awal merintis itu modalnya kecil aja, tapi karena makin hari keliatannya tambah banyak, tambah banyak pelanggan akhirnya ya kita tambah"

Menurut beliau dengan sedikitnya modal yang dibutuhkan berarti tenaga yang dibutuhkan juga tidak begitu banyak. "karena salome ini tidak terlalu membutuhkan tenaga banyak, biaya banyak, tapi hasilnya cukup memuaskan untuk kita. Jadi itu yang membuat kita bertahan."

Bapak Niko yang sudah berpengalaman dalam dunia usaha akhirnya tertarik dengan salome. Beliau berfikir bahwa salome meruBapakan makanan kecil yang memiliki peluang sangat bagus, sangat menguntungkan bila ditekuni dan tidak memakan banyak waktu. "Peluang yang paling bagus, makanan kecil, terus yang lebih bagus lagi ya salome, karena kerjanya simple hasilnya lumayan". Selain itu sebagai mantan seorang pengusaha beliau berkata bahwa profesi sebagai penjual salome dianggap remeh oleh segelintir orang, namun menurut beliau berjualan salome dapat lebih bagus dari pada usaha-usaha yang terlihat mewah. Hal ini yang membuat beliau lebih tertarik lagi kepada salome. Seperti yang dikatakan beliau kepada peneliti bahwa "salome ini kelihatannya sepele, tapi hasilnya cukup memuaskan. Jadi memang keliatannya salome atau penjual salome itu dianggap remeh, tapi kalau dihitung-hitung salome ini lebih bagus dari pada usaha-usaha lainnya yang kelihatannya mewah. Usaha yang mewah itu belum pertama, untuk sewa tempatnya, gaji anak buahnya, yang ketiga dia harus keluarkan biaya-biaya yang lain yang ekstra lebih banyak dari pada salome. Kalau salome ini sekalipun dia Bapake rombong sendiri tapi hasilnya cukup memuaskan".

Bapak Niko yang sudah lama berjualan salome menceritakan bagaimana suka dan dukanya berjualan salome, karena sebagai PKL pastinya banyak ketentuan-ketentuan yang wajib ditaati saat berjualan.

"Yaaaa ada sukanya karena dapat hasilnya bagus. Dukanya ya itu dikejar-kejar sama pamong, karena kita disini kan namanya PKL, itu artinya Pedagang Kaki Liar, kakinya liar jadi dia tidak menetap. Artinya selalu melanggar peraturan daerah, peraturan daerah ini yang ditertibkan oleh satpol pp, dari pihak wali kota 
turun ke satpol pp, satpol pp yang menertibkan".

Setelah kurang lebih 12 tahun menjadi seorang penjual salome, banyak sekali hal-hal yang dialami oleh Bapak Niko. Saat setelah peneliti memberikan banyak pertanyaan kepada informan, terdapat beberapa hal menarik mengenai mengapa Bapak Niko tetap bertahan dan bagaimana Bapak Niko memaknai keuntungan sebagai penjual salome.

Makna yang pertama adalah biaya modal yang kecil, namun keuntungan memuaskan. Menurut Bapak niko, berjualan salome tidak membutuhkan biaya modal yang banyak, sebagaimana biaya modal pada usaha-usaha mewah, tetapi keuntungannya memuaskan. Berikut penuturan Bapak Niko,

"Salome ini kelihatannya sepele, tapi hasilnya cukup memuaskan. Jadi memang keliatannya salome atau penjual salome itu dianggap remeh, tapi kalau dihitung-hitung salome ini lebih bagus dari pada usaha-usaha lainnya yang kelihatannya mewah. Usaha yang mewah itu belum pertama, untuk sewa tempatnya, gaji anak buahnya, yang ketiga dia harus keluarkan biaya-biaya yang lain yang ekstra lebih banyak dari pada salome. Kalau salome ini sekalipun dia Bapake rombong sendiri tapi hasilnya cukup memuaskan."

Tenaga juga tidak banyak yang dikorbankan. Beliau menambahkan alasan mengapa beliau mampu bertahan 12 tahun berjualan salome. Beliau mengatakan, "karena salome ini tidak terlalu membutuhkan tenaga banyak, biaya banyak, tapi hasilnya cukup memuaskan untuk kita. Jadi itu yang membuat kita bertahan." Dari hasil berjualan salome Bapak Niko sudah bisa beli rumah, beli mobil, dan beli motor.

Bapak Niko mampu memenuhi kebutuhan sehari-harinya dengan berjualan salome dan dapat membeli beberapa asset. Walaupun sekarang penjual salome semakin banyak, Bapak Niko tetap merasakan keuntungan dan tidak berfikir untuk berpindah profesi. Menurut beliau jika terus ditekuni penjualan salome ini sangat membantu perekonomiannya.

Makna kedua Bapak Niko merasa dengan berjualan salome memiliki waktu yang feksibel dan tidak dalam tekanan.

"keuntungan bagi kita seorang PKL, khususnya salome ini kan netral. Netral dalam arti itu tidak diperintah oleh siapapun, jadi semau kita kerja, kapanpun kita berangkat kapanpun kita pulang kita tidak terlalu terhitung dengan waktu".

Menurut beliau profesi penjual salome ini sangat mudah. Tidak perlu dikejar-kejar oleh waktu. Pada saat sehat dapat berjualan hingga batas waktu yang diinginkan. Namun pada saat kondisi yang buruk dapat tidak berjualan hingga waktu yang tidak ditentukan pula. Bapak Niko akan sesuka hatinya berjualan karena tidak ada Bapaksaan, tidak ada pula yang akan memarahinya jika tidak berjualan. Seperti yang dikatakan kepada peneliti "dari segi waktu, kedua dari segi tidak diperintah orang. Jadi namanya usaha sendiri itu tidak tertekan, tidak terikat oleh orang lain. Kalau tidak terikat jadi kita ini kerjanya simple, mau sewaktuwaktu kita jualan, kapan kita mau 
pulang itu tergantung dari pribadi kita sendiri”.

\section{Tenaga yang Sedikit, Keuntungan Mending (lumayan)}

Bapak Sumijan merupakan salah satu pedagang yang telah lama bekerja sebagai penjual salome di Balikpapan. Ia telah berjualan selama kurang lebih 28 tahun sejak tahun 1991. Beliau telah mencoba berbagai jenis pekerjaan dalam perantauannya sebelum memutuskan untuk menjual salome hingga saat ini. Bapak sumijan sendiri berasal dari Pati- Semarang, Jawa Tengah. Awal mula memutuskan untuk tinggal di Balikpapan ialah pada tahun 1981 ketika saat itu beliau masih berusia 24 tahun dengan status belum menikah. Beliau menyampaikan kepada peneliti "tujuan ke Balikpapan cari penghidupan yang lebih baik supaya sejahtera hidup anak cucu kita." Di kota ini, ia mencoba berbagai macam jenis pekerjaan untuk memenuhi kebutuhan hidup dengan hanya bermodalkan pendidikan terakhir berupa Sekolah Dasar. Beliau menjelaskan kepada peneliti, "kerjaan pertama, jualan bubur kacang ijo, kedua pernah kita ngalami tukang ojek, ada 3 tahun, terus habis itu kita jualan lagi jualan bakso. Jualan bakso kalau gak salah tahun 88 , oh 87 akhir lah, sampai tahun 90."

Dalam melakukan pekerjaannya sehari-hari sebagai penjual salome, Bapak Sumijan menjajakan dagangannya dengan cara berkeliling menggunakan alat pikulnya, namun dengan kondisi kesehatan yang menurun seiring bertambahnya usia, Bapak Sumijan memutuskan untuk menjajakan dagangannya di 2 tempat tertentu saja yaitu di depan SDN 018 Balikpapan Barat ketika jam sekolah berlangsung, dan setrat Jumpi (pinggir Jalan Jumpi- kampung baru) setelahnya. Beliau menjelaskan kepada peneliti “...
Pada waktu dari babak pertama, waktu kaki belum sakit keliling (jualannya). Habis keliling terus disini . karna sakit kaki ndak bisa sudah ya." BaBapak sumijan menjual dagangannya menggunakan alat pikul, sebab apabila menggunakan pikulan, ia bisa menjangkau tempat-tempat yang tidak bisa dilalui oleh motor seperti lorong kecil hal itu akan menambah keuntungan penjualannya. BaBapak Sumijan mulai berjualan pada pukul 9 pagi hingga malam hari sampai barang dagangan habis. Beliau memberikan penjelasan kepada peneliti.

"mulai pagi, ya gampangannya jam 9 sampai nanti setengah 1 , pulang istirahat sholat dhuhur. Habis sholat ashar terus kesini sampai tinggal nurut dari barang atau pembeli, kalau seandainya sudah jamnya pembeli gak ada, barang gak ada, pulang. Tapi, kalau seandainya pembeli berlarut-larut gak ada putus dilanjutkan sampai habis barang. Asal gak ada putus. Kalo ada putus, sudah jam nya kita pulang. Itu kalau sebagai orang jualan dilembur. Ndak ceritanya misalpun ada barang kita nolak pembeli, tidak."

Bagi Bapak Sumijan, tidak ada waktu libur khusus untuk tidak berjualan, beliau mengatakan akan libur, ketika ada kepentingan tertentu saja, seperti keluarga yang sakit, ataupun tetangga dekat yang meninggal dunia.

Melihat dari latar belakang keluarga Bapak Sumijan, diketahui bahwa tidak ada ada darah pedagang yang diturunkan dari orang tuanya. Orang tua Bapak Sumijan sendiri merupakan seorang perangkat desa di Semarang atau dikenal sebagai pegawai lurah di Kota. Ketika ditanya beliau 
menyampaikan kepada peneliti "Kalau di jawa pegawainya kepala desa, tapi bawahnya kalau orang tua, bapak kan. kalau disebut pulau jawa namanya kebayan , perangkat desa itu loh." Pertama kalinya beliau memutuskan untuk menjadi pedagang ialah ketika beliau merantau ke Balikpapan. Berbagai macam jenis dagangan telah Ia coba hingga akhirnya menetap sebagai penjual salome.

Bapak Sumijan menceritakan pada saat pertama kali memutuskan untuk berjualan salome, Ia memperoleh modal awal dari hasil menjual kendaraan bermotor yang Ia miliki saat di kampung dahulu. "Pada waktu itu kita pulang kan punya motor kita jual, ada sisanya dan untuk modal." Beliau mengatakan modal awal pada saat itu berkisar Rp 7.000 rupiah. Dengan modal tersebut, Ia dapat memperoleh keuntungan 2 kali lipat yaitu sebesar $\mathrm{Rp}$ 15.000. berikut penjelasan Bapak Sumijan kepada peneliti,

“...Untung jaman dulu, pada waktu Rp 7.000 modal, bisa aja ada keuntungan Rp15.000. waktu pentolan (salome) masih 1 cucuk harga Rp50,- Rupiah . pendapatan semuanya kalau belum potong modal diatas Rp20.000. Umpama mendapatkan Rp22.000, kita kan 15.000 (untungnya) iya kan gitu kalau jaman dulu. Yang harga Rp50/tusuk itu tahun 1991 sampai tahun 2000. Nah, naik lagi Rp100/tusuk tahun 2000 sampai tahun 2004. Terus 2004 sampai sekarang ini Rp500/tusuk tetap gak ada naiknaik."

Untuk saat ini keuntungan yang Ia peroleh berkisar Rp100.000 sampai Rp150.000 per hari. Tetapi terkadang apabila kondisi cuaca buruk seperti hujan, Bapak Sumijan mengatakan bahwa Ia bisa tidak memperoleh keuntungan sama sekali, hanya memperoleh modal kembali dan akan disambung lagi esok hari. Bapak Sumijan juga mengatakan Ia tidak melakukan pencatatan akuntansi mengenai modal dan keuntungannya, hanya mengandalkan ingatan nya saja dari awal berjualan hingga saat ini.

Berjualan salome selama berpuluh-puluh tahun bukanlah waktu yang singkat. Hal ini menarik perhatian peneliti untuk mengetahui lebih dalam alasan Bapak Sumijan untuk tetap bertahan pada 1 jenis pekerjaan tersebut. Ketika ditanyakan lebih jauh, Alasannya ialah karena dengan berjualan salome memberikan keuntungan yang lebih besar dibandingkan dengan berjualan yang lain dan juga lebih ringan tenaga dibanding pekerjaan yang lain. "pada waktu itu belum ada penjual kita yang sehari 'ringan tenaga gajih mending' gitu, termasuk gaji lumayan. Betul ndak...." Saat peneliti melontarkan beberapa tema pertanyaan mengenai bagaimana Bapak Sumijan memaknai keuntungannya hingga beliau mampu bertahan berdagang salome hingga 28 tahun, Bapak Sumijan menyatakan bahwa keuntungan berjualan salome adalah tenaga yang ringan dengan profit yang lumayan besar. BaBapak Sumijan menjelaskan kepada peneliti "seperti yang saya bilang ringan tenaga, gajih mending dan pada waktu itu belum banyak orang jual. yah masalah keuntungan itu berwujud duit. Seandainya ada pembayaran lampu pembayaran air telpon, itu nanti dipotong untuk itu. Bisa beli kebun, bisa bikin rumah, yah sambil biayai anak sekolah. Sedikit-sedikit adalah untuk ditabung." 
Menurut Bapak Sumijan dengan keuntungan yang beliau peroleh setiap harinya, uang tersebut dapat beliau gunakan untuk membiayai keperluan sehari-hari, membiayai sekolah ketiga anaknya serta untuk investasi masa depan dengan cara menabung sebagian keuntungannya. Bapak Sumijan juga mengungkapkan bahwa beliau dapat membeli kebun serta membangun rumah. Hal ini menunjukkan bahwa dengan hasil berjualan salome Bapak Sumijan masih bisa menyisihkan uangnya untuk kebutuhan lainnya diluar kebutuhan sehari-hari. Dengan penghasilan yang beliau peroleh setiap harinya, hal itu dapat membantunya memenuhi kebutuhan serta menghidupi keluarganya.

\section{Adanya Harapan Melakukan Investasi untuk Masa Depan}

Bapak Suyatno adalah penjual salome yang berjualan di depan SMP Patra Dharma I. Salome yang beliau jual terkenal dengan nama Salome Goreng Ipul PD. Bapak Suyatno yang telah berjualan salome selama 17 tahun, mengaku kalau beliau memang memiliki niat untuk berjualan. Beliau merasa berjualan adalah jiwanya dan didukung oleh pekerjaan Ayahnya yang juga berjualan, bahkan mertua beliau sebelumnya juga berjualan salome. Beliau juga menyampaikan bahwa seandainya disuruh untuk bekerja dengan gaji lumayan pun ia akan tetap memilih untuk berdagang.

Bapak Suyatno berasal dari Solo. Beliau bercerita sempat berjualan Bakso di Jakarta, namun pada tahun 2002 beliau ke Balikpapan dan memutuskan untuk berjualan salome. Beliau menjelaskan alasannya memutuskan berjualan salome adalah sebagai berikut :

"Yang jelas kalo dagang itu sudah jelas. Maksudnya sudah jelas itu pasti, pasti setiap hari penghasilan itu ada. Gak harus menunggu sebulan sekali kan gitu. Yang kedua itu waktu, waktu itu jelas toh. Kalo seandainya kita kerja, kita kan ikut sama orang jadi ya namanya disuruh-suruh. Yang ketiga itu kalo kita jualan sendiri yang jelas enak lah mau libur setiap hari mau bagaimana mau acara apapun itu bisa kita yang ngatur. Gak diatur sama orang."

Beliau merasa berjualan salome lebih mudah dilakukan sehingga memutuskan untuk berpindah profesi dari penjual bakso menjadi penjual salome. Menurut beliau, di Balikpapan situasi dan kondisinya masih menjanjikan untuk berjualan salome. Beliau betah berlama-lama berjualan salome bukan tanpa alasan, yakni beliau merasa berjualan salome sangat menjanjikan untuk memenuhi kebutuhan keluarganya. Bapak Suyatno juga menambahkan kalau berjualan salome ini lebih enak daripada berjualan bakso seperti sebelumnya. Beliau tidak perlu mengeluarkan tenaga dan biaya yang lebih karena dalam berjualan salome itu pekerjaannya lebih ringan dan praktis.

Dalam berjualan salome, Bapak Suyatno mengatakan modal yang dikeluarkan cukup banyak berkisar 750 ribu rupiah. Beliau harus pintar mengatur keuangannya agar mendapat keuntungan yang maksimal. Apabila bahan masih ada beliau tidak perlu belanja lagi, karena apabila belanja bahan lagi maka beliau bisa tidak mendapatkan untung. “...Y Yang penting menghabiskan itu dulu. Karena apa? Kita sudah rugi waktunya satu hari."

Bapak Suyatno menjelaskan, Beliau kesulitan mencari tempat. Awalnya beliau berjualan di sekolah- 
sekolah dengan berkeliling, tapi sekarang beliau sudah menemukan sekolahan yang tepat dan berjualan menetap di sana. Saat berjualan salome terkadang keuntungan yang diperoleh menipis jika dalam kondisi seperti sedang hujan atau saat Ramadhan. Sering pula salomenya cepat habis jika sedang ada acara seperti jalan santai dan lainnya.

Selama 17 tahun berjualan, sudah ada sangat banyak hal yang dirasakan oleh Bapak Suyatno ketika berjualan salome. Mulai dari suka maupun duka serta hal menarik lain yang dapat ditelusuri mengenai alasan beliau mau bertahan berjualan dalam waktu yang sangat lama. Sebagai penjual salome, Bapak Suyatno memaknai keuntungannya dikaitkan dengan adanya harapan untuk investasi di masa depan. Bapak Suyatno mengakui bahwa dari hasil berjualan salomenya dapat digunakan untuk menunjang masa depan. Beliau merasa dalam hidupnya terdapat peningkatan yang dirasakan dari kemampuannya untuk menyekolahkan anaknya dan membangun rumah dari hasil berjualan salome. Beliau juga mengatakan dari berjualan salome ini beliau dapat melakukan investasi untuk masa depan keluarganya.

"Ya jadi gini, untuk harapan masa depan itu kan yang saya maksudkan dalam kebutuhan untuk kebutuhan sehari-hari sudah tercukupi dan masih ada sisanya kan gitu. Jadi sisanya memang untuk masa depan anak-anak. Contohnya Alhamdulillah untuk anak-anak tak bayarkan asuransi. Terus untuk tabungan anak-anak untuk masa depannya kan."

Selain itu Bapak Suyatno juga mengatakan di luar untuk kebutuhan sehari-hari, sisa keuntungan yang dimiliki memang beliau investasikan pada tanah dan rumah. Saat ini beliau sudah mempunyai dua rumah kontrakan yang juga dapat menambah pemasukannya setiap bulan.

Motivasi yang membuat Bapak Suyatno bersemangat menekuni profesi penjual salome ini adalah demi masa depan anak. Beliau mempunyai keinginan agar anaknya sekolah sampai jenjang yang tinggi. Beliau juga berkata telah mempersiapkan asuransi untuk pendidikan anaknya di masa depan sehingga ia tak perlu memikirkannya lagi. “...Ya pokoknya masing-masing anak udah mulai tak asuransi untuk pendidikan kan. Jadi nanti seandainya sudah kuliah itu nanti tinggal kuliah gitu. Bahkan asuransi juga hasil dari salome ini."

Dari hasil berjualan salome ini Bapak Suyatno mengaku sudah ada bukti nyata peningkatan yang ia rasakan sejak dulu. Ia mampu menyekolahkan anaknya dan sudah membangun rumah sendiri bahkan kini ia sudah mempunyai kontrakan. Dengan begitu, dari keuntungan berjualan salome ini dimaknai oleh Bapak Suyatno sebagai harapan investasi untuk masa depan keluarganya.

\section{Keuntungan "laba" Dapat Mencukupi Kebutuhan Keluarga}

Salome Bapak Kumis adalah salah satu dari sekian banyak penjual salome yang berjualan di Balikpapan, tepatnya di depan SD Patra Dharma I. Bapak Sutokim Andreas selaku pemilik dari Salome Bapak Kumis mengaku telah berjualan sejak tahun 2008 atau kurang lebih selama 11 tahun. Beliau berjualan setiap hari Senin sampai Sabtu mulai pukul 09.00 sampai pukul 18.00 dan terkadang ditemani oleh istrinya. Bapak Sutokim berasal dari 
Gresik provinsi Jawa Timur yang kemudian pertama kali merantau ke Berau untuk berjualan bakwan, nasi goreng, batagor dan mie goreng.Namun karena ada urusan pribadi, Bapak Sutokim terpaksa harus kembali ke kampung halamannya. Setelah beberapa lama, Bapak Sutokim kembali merantau tetapi kali ini ke Balikpapan berdasarkan permintaan Kakaknya.

Bapak Sutokim yang bukan merupakan orang asli Balikpapan awalnya sedikit bingung untuk memulai pekerjaan di Balikpapan. Beliau sebelumnya sudah berjualan berbagai makanan saat di Berau namun berkat saran dari Kakaknya, akhirnya Bapak Sutokim memutuskan untuk berjualan salome di Balikpapan walaupun pada saat itu beliau tidak mengetahui apa itu 'salome'. "...Pas hari itu saya pernah orang liat bikin salome, tapi saya liat aja udah tau," kata beliau kepada peneliti. Kakak dari Bapak Sutokim merupakan penjual Nasi Goreng yang lebih dulu berjualan dan sangat mendukung Bapak Sutokim untuk berjualan salome. Kakak beliau bersedia meminjamkan uang sebagai modal awal untuk Bapak Sutokim berjualan salome. Berikut penjelasan beliau saat menceritakan awal mula memulai usahanya.

"Saya dulu pertama kan ke berau juga saya jualan.Pas mau berhasil disuruh pulang kerumah berapa tahun.Terus dipanggil kesini.Kan kakak saya jualan nasi goreng. Saya kesini, sama kakak saya 'Sudah disini aja jualan salome'. 'Salome? Oiya.Ya modale?' 'Gampang, nanti dipinjami'.Saya beli sepeda motor, beli rombong, jualan keliling udah. Keliling baru ada jual rombong tak beli, tak mangkalkan disitu kan, kok cepet abis, rame, akhirnya saya berenti keliling, mau mangkal disitu aja. Jadi rame sudah."

Bapak Sutokim bercerita bahwa modal awal yang dia keluarkan sekitar hampir 2 juta rupiah dan itu cukup sulit baginya untuk balik modal. Sekarang dengan modal sekitar 1 juta rupiah, Bapak Sutokim sudah bisa meraup untung sampai Rp 500.000,00. Beliau tidak melakukan pencatatan pengeluaran dan hanya mengandalkan ingatannya saja

Bapak Sutokim menjelaskan kalau beliau tidak memiliki darah dagang dari orang tua tetapi beliau memiliki seorang Kakak yang berjualan Nasi Goreng di Balikpapan. Bapak Sutokim yang hanya lulusan SD bercerita pada saat awal berjualan beliau masih berjualan keliling dan banyak sekali kesulitan yang ia alami. Beliau sempat merasakan bagaimana terkena razia pamong praja pada saat berjualan "Sampe rombong diangkut pamong praja. Jadi kita pulang cuma bawa sepeda motor. Kisahnya banyak waktu masih keliling belum mangkal. Sudah keliling susah, rombong dibawa pamong praja, kita dua kali". Beliau juga menambahkan kalau faktor cuaca juga merupakan kesulitan yang sering dialami.

Berjualan selama belasan tahun bukanlah waktu yang singkat. Bapak Sutokim sendiri memiliki alasan mengapa betah berlama-lama berjualan salome. Bapak Sukokim mengungkapkan kepada peneliti bagaimana beliau memaknai keuntunganmya. Menurut Bapak Sutokim berjualan salome mampu menghasilkan keuntungan yang dapat mencukupi kebutuhan keluarga. Berikut penjelasan beliau kepada peneliti: "Ada hasilnya kan? Kuliahkan anak saya dua. Berhasilnya salome bisa lulus anak saya dua. Di Jawa juga bikin rumah. Jualan 
salome aja sudah. Bisa buat menuhin kebutuhan apa-apa. Gak lain-lain kan. Gak ada tenaga juga."

Bapak Sutokim memiliki tiga orang anak dan saat ini hanya tinggal satu anak yang masih menjadi tanggungannya. Beliau merasa penghasilan dari berjualan salome sudah cukup, karena bebannya saat ini sudah ringan. Beliau bahkan sudah mempersiapkan seluruh biaya untuk masa depan anaknya nanti. "Ya itu yang masih kecil. Cuma biaya sudah ringan beban. Ini tinggal satu udah saya masukan asuransi belajar dari prudensial. Buat persiapan biaya sekolah. Kita kan sudah tua, anak masih kecil. Jadi persiapan sekolah."

Bapak Sutokim tidak memiliki keinginan untuk berganti profesi. Beliau merasa sudah tidak punya tenaga dan apabila membuka cabang hanya akan menambah pengeluaran.

"Kalau saya sih udah enggak. Apalagi kalau tenaga sudah tua. Udah gini aja. Mau buka cabang juga tenaganya udah gak ada. Mau bayar orang ya itu, daripada. Udah terlalu banyak pikiran lalu dibuat sendiri. Dulu sudah ada orang nyari buka cabang. Udah cari tempat. Tapi saya udah gamau udah. Gak ada tenaga ini. Mending sendiri."

Bapak Sutokim mampu menguliahkan anak, membangun rumah bahkan sudah bisa merencanakan masa depan anaknya dengan pendapatan hasil berjualan salome. Hal ini menunjukkan bahwa dengan hasil berjualan salome selain untuk kebutuhan sehari-hari masih ada sebagian dari pendapatannya yang bisa disisihkan. Dengan aliran kas yang stabil dan mencukupi ini Bapak Sutokim merasa tidak perlu beralih profesi lain.

\section{Konstruksi Makna: Segmen Pasar Luas, Modal Ringan, dan Fleksibilitas Pengelolaan Usaha.}

Berdasarkan kesadaran informan dapat dikonstruksikan tiga makna keuntungan berjualan salome yaitu segmen pasar luas, modal ringan, dan fleksibilitas pengelolaan usaha. Makna segmen pasar luas didapatkan dari kesadaran Bapak Bangit pada tema 4.1. mengenai luasnya segmen pasar penikmat produk salome, yaitu mulai anak-anak hingga dewasa. Makna modal ringan disarikan dari pernyataan Bapak Slamet, Bapak Niko, dan Bapak Sumijan Pada tema 4.3., 4.4., 4.5. Mereka sepakat bahwa investasi di usaha salome membutuhkan modal dan tenaga yang ringan. Makna fleksibilitas pengelolaan usaha disarikan dari kesadaran Bapak agus dan Bapak Niko pada tema 4.2. dan tema 4.4. Menurut Bapak Agus dan Bapak Niko mengelola usaha salome waktunya bisa sangat fleksibel. Semua pengambilan keputusan ada di masing-masing penjual. Mau berjualan jam berapa pun terserah kepada penjual. Tidak dituntut dengan banyak aturan-aturan

\section{Sintesis Makna Keuntungan Penjual Salome}

Keuntungan yang dipersepsikan oleh penjual salome pada hasil penelitian menghasilkan temuan keuntungan yang sifatnya holistis. Makna keuntungan yang didapatkan dari kesadaran penjual salome tidak hanya makna keuntungan yang bersifat laba akuntansi. Penjual salome yang telah lama menekuni profesinya merasa bahwa profesi penjual salome merupakan profesi yang memiliki prospek bagus setidaknya dilihat dari aspek strategis, keuangan dan operasional. Dilihat dari aspek strategis profesi penjual salome memiliki keuntungan segmen pasar yang luas. 
Melalui pernyataannya Bapak Bangit mengatakan bahwa salome sebagai produk camilan yang digemari oleh semua kalangan dari anak sekolah hingga orang tua. Melalui segmen pasar yang luas ini perputaran penjualan produk salome cukup cepat, sebagaimana disampaikan oleh Bapak Agus bahwa waktu yang dibutuhkan untuk berjualan salome lebih efisien, karena salome cepat habisnya.

Dari aspek

keuangan keuntungan berjualan salome dimaknai dari aspek permodalan yang ringan. Menurutnya berjualan salome tidak membutuhkan biaya modal yang besar, namun laba akuntansi yang didapatkan besar. Hampir semua informan menyatakan ada hasil nyata dari profesi yang ditekuninya sebagai penjual salome. Makna ini sebagaimana disampaikan oleh Bapak Slamet, Bapak Niko, dan Bapak Sumijan dimana mereka sepakat modal dan tenaga yang dibutuhkan untuk berjualan salome tidaklah besar. Mereka juga sepakat bahwa salome menghasilkan keuntungan yang memuaskan. Keuntungan tersebut sebagian digunakan untuk memenuhi kebutuhan pokok keluarga, dan sebagian sisanya digunakan untuk investasi masa depan, seperti membiayai pendidikan anak, membangun rumah, membeli motor, dan aset masa depan lainnya.

Dari aspek operasional keuntungan berjualan salome dimaknai sebagai keuntungan dalam hal fleksibilitas pengelolaan. Menurut Bapak Agus dan Bapak Niko mengelola usaha salome waktunya bisa sangat fleksibel. Semua pengambilan keputusan ada di masing-masing penjual. Mau berjualan jam berapa pun terserah kepada penjual. Tidak dituntut dengan banyak aturan-aturan, sebagaimana ditemukan dilingkungan kerja kantoran. Bapak Agus juga menyatakan bahwa beliau mendapatkan keuntungan berupa kepuasan batin selama menekuni usaha salome, apalagi beliau dengan bebas mampu mengelola keseimbangan waktu untuk berjualan dan untuk beribadah kepada Allah.

\section{Kontribusi Temuan Makna Keuntungan \\ Pengukuran kinerja}

menggunakan aspek finansial seperti profitabilitas dan solvabilitas sudah umum dilakukan dalam bidang bisnis. Laba akuntansi yang merupakan proksi utama dari profitabilitas menjadi pertimbangan yang banyak dipakai oleh pengambil keputusan dalam mengelola bisnis. Penelitian ini memberikan perspektif lain dalam melakukan pengukuran kinerja bisnis UMKM, khususnya terkait informasi non finansial seperti penelitian yang dilakukan oleh Sajuti (2016)

Bisnis UMKM memiliki karakteristik yang berbeda dari bisnis korporasi. Beberapa perbedaan tersebut terlihat dari struktur modal, aspek pengelolaan resiko bisnis, hingga konsistensi pelaporan keuangan. Menurut Sajuti (2016) UMKM memiliki karakteristik pengelolaan risiko yang berbeda dengan perusahaan korporasi. Dalam mengukur paparan resiko bisnis UMKM dibutuhkan juga informasi non-finansial, seperti karakteristik usaha dan aspek risiko operasional. Hal ini disebabkan pada beberapa UMKM sulit didapatkan infomasi finansialnya disebabkan karena ketidakkonsistenan dalam menyediakan laporan keuangan.

Temuan penelitian makna keuntungan dari penjual salome menunjukkan beberapa informasi non finansial yang dapat dijadikan pertimbangan dalam melakukan pengukuran kinerja bisnis salome. Informasi seperti segmen pasar yang 
luas, kecepatan perputaran penjualan, dan fleksibilitas pengelolaan merupakan informasi penting non finansial yang dapat dipertimbangkan dalam mengukur kinerja bisnis salome. Pertimbangan Informasi non finansial tersebut bermanfaat bagi lembaga keuangan atau lembaga penyalur modal usaha dalam menilai risiko bisnis salome atau menambahkan elemen-elemen non finansial tersebut ke dalam model pengukuran risiko bisnis UMKM.

\section{PENUTUP}

\section{kesimpulan}

Berdasarkan hasil penelitian ditemukan makna keuntungan berjualan salome menurut kesadaran penjual salome, yaitu segmen pasar yang luas, modal usaha ringan, dan fleksibilitas pengelolaan usaha. Makna keuntungan tersebut mencerminkan prospek masa depan yang baik dilihat dari aspek strategis, keuangan, dan operasionalnya. Segmen pasar produk salome yang luas merupakan aspek strategis. Melalui segmen pasar yang luas ini perputaran penjualan produk salome cukup cepat, sehingga akan berdampak pada stabilitas perolehan laba akuntansi dalam jangka panjang.

Pada aspek keuangan berjualan salome membutuhkan modal yang ringan, baik dari modal kerja maupun sumber daya manusianya. Meskipun demikian sebagian besar informan mengakui keuntungan dari usaha ini cukup memuaskan. Pada aspek operasional pengelolaan usaha salome sangat fleksibel, khususnya dari segi waktu dan prosedur kerja. Hal ini memberikan kebebasan kepada penjual salome salah satunya dalam pengambilan keputusan terkait pengelolaan keseimbangan waktu untuk berjualan dan untuk beribadah kepada Allah.
Temuan penelitian ini juga dapat memberikan wawasan tambahan salah satunya bagi lembaga keuangan atau lembaga penyalur modal mengenai prospek usaha salome. Temuan ini juga dapat dijadikan pertimbangan dalam menilai paparan risiko bisnis salome jika dilihat dari aspek strategis, keuangan, dan operasional. Informasi non finansial memberikan gambaran yang lebih holistis mengenai risiko yang didapatkan pada bisnis salome.

\section{Saran}

Penelitian ini diharapkan mampu membuka wawasan baru mengenai analisis risiko kinerja UMKM, khususnya pada usaha salome. Dalam pengukuran risiko usaha salome hendaknya melihat juga aspek strategis dan operasional, selain aspek keuangan. Mengingat beberapa UMKM tidak membuat laporan keuangan, seperti usaha salome yang dijadikan obyek penelitian ini.

Bagi pemerintah penelitian ini diharapkan mampu memberikan masukan yang bijak mengenai penertiban pedagang kaki lima. Peneliti menyarankan sebaiknya pemerintah memberikan kompensasi penyediaan tempat yang strategis bagi penjual salome yang ditertibkan pada lokasi yang memang tidak layak dijadikan tempat berjualan. Sebagian besar informan pada penelitian ini mengambil tempat yang strategis, seperti sekitar lingkungan sekolah, pasar, taman dan pusat keramaian untuk menjajakan dagangannya. Alangkah baiknya pemerintah mengarahkan dan mengijinkan penjual salome untuk menempati lokasi-lokasi tersebut dengan syarat dan ketentuan yang disepakati bersama.

Bagi lembaga keuangan dalam melakukan pengukuran risiko bisnis 
UMKM, seperti penjual salome, sebaiknya menambahkan variabel non finansial. Dalam beberapa hal perlu dilakukan analisis strategis dan operasional untuk mengetahui secara mendalam prospek masa depan bisnis UMKM tersebut. Hal demikian menjadi pertimbangan penting mengingat keterbatasan informasi finansial yang didapatkan bagi UMKM yang tidak taat menyusun pelaporan keuangannya.

\section{DAFTAR PUSTAKA}

Akhadiyah, N., \& Jatiningsih, O. (2017). Resistensi Pedagang Kaki Lima Alun-alun Kota Mojokerto Terhadap Kebijakan Relokasi Pemerintah Kota Mojokerto. Kajian Moral Dan Kewarganegaraan, 5(1), 348362.

Creswell, J.,W. (2015). Penelitian Kualitatif \& Desain Riset: Memilih di Antara Lima Pendekatan. Edisi Ketiga. Yogyakarta: Pustaka Pelajar.

Prabowo, U., \& Handoyo, P. (2016). Peran Modal Sosial dalam Mekanisme Survival Pedagang Kaki Lima ( PKL ) Pentol Bakar di Kawasan Benteng Pancasila ( BenPas ) Kota Mojokerto Unggul Prabowo Pambudi Handoyo Abstrak. Paradigma, 4(1), 1-10.

Sajuti, R. (2016). Analisis agribisnis ayam buras melalui pendekatan fungsi keuntungan multi output kasus Jawa Timur. Jurnal Agro Ekonomi, 19(2), 56-74.

Wafirotin, K., Z \& Dwiati, M. (2015). Persepsi Keuntungan Menurut Pedagang Kaki Lima di Jalan Baru Ponorogo. Jurnal Ekulilibrium. 13 (2):24-36. 